\title{
Archives and Special Collections
}

Compiled by Anna Appleman

Burns, Mary. “RDA and Rare Books Cataloging, Part 1." Library Resources \& Technical Services 62, no. 4 (October 2018): 160-175.

Burns, Mary. “RDA and Rare Books Cataloging, Part 2." Library Resources \& Technical Services 63, no. 1 (January 2019): 4-28.

Levine-Clark, Michael. "Are Print-Only Special Collections Relevant in the Digital Era? How Digital Sources Can Expand and Redefine a Collection's Value.” Choice: Current Reviews for Academic Libraries 56, no. 3 (November 2018): 286-87.

Mitra, Sanjukta, and Swapna Banerjee. "Information Management in Special Archives of Kolkata: A Case Study.” DESIDOC Journal of Library \& Information Technology 39, no. 3 (May 2019): 139-42. DOI: https://doi. org/10.14429/djlit.39.3.13914

Stewart, Kelly, and Stefana Breitwieser. “SCOPE: A Digital Archives Access Interface.” Code4Lib Journal, no. 43 (February 14, 2019): 1. https://journal.code4lib.org/articles/14283

Turner, Rachel Berman, and David Schuster. "Carts in the Hallway: Cataloging and Special Collections-A Partnership for Success.” Technical Services Quarterly 36, no. 2 (April 2019): 142-54. 